Article

\title{
Arc Brazing of Aluminium, Aluminium Matrix Composites and Stainless Steel in Dissimilar Joints
}

\author{
Thomas Grund ${ }^{1, *}$, Andreas Gester ${ }^{1}$, Guntram Wagner ${ }^{1}$ (D), Stefan Habisch ${ }^{2}$ and Peter Mayr ${ }^{2}$ (i) \\ 1 Institute of Materials Science and Engineering, Chemnitz University of Technology, 09127 Chemnitz, \\ Germany; andreas.gester@mb.tu-chemnitz.de (A.G.); guntram.wagner@mb.tu-chemnitz.de (G.W.) \\ 2 Institute of Joining and Assembly, Chemnitz University of Technology, 09126 Chemnitz, Germany; \\ stefan.habisch@mb.tu-chemnitz.de (S.H.); peter.mayr@mb.tu-chemnitz.de (P.M.) \\ * Correspondence: thomas.grund@mb.tu-chemnitz.de; Tel.: +49-371-531-35390
}

Received: 30 January 2018; Accepted: 5 March 2018; Published: 8 March 2018

\begin{abstract}
The publication describes the approaches and results of the investigation of arc brazing processes to produce dissimilar joints of particle reinforced aluminium matrix composites (AMC) to aluminium alloys and steels. Arc brazing allows for low thermal energy input to the joint parts, and is hence suitable to be applied to AMC. In addition, a braze filler B-Al40Ag40Cu20 alloyed with Si with a liquidus temperature of below $500{ }^{\circ} \mathrm{C}$ is selected to further reduce the thermal energy input during joining. The microstructures of the joining zones were analysed by scanning electron microscopy (SEM), energy dispersive X-ray spectroscopy (EDXS), and X-ray diffraction analysis (XRD), as well as their hardness profile characterised and discussed. Joint strengths were measured by tensile shear tests, and resulting areas of fracture were discussed in accordance to the joints' microstructures and gained bond strength values.
\end{abstract}

Keywords: arc brazing; brazing fillers; microstructure; wettability; aluminium matrix composite; AMC; stainless steel; aluminium; joining

\section{Introduction}

Dissimilar metal joints under presence of light metals show a high potential to further improve existing light weight solutions, since they strongly widen the design flexibility of components and assemblies. To this design flexibility, high performance materials, like aluminium matrix composites (AMC), add further advantages regarding the mechanical and physical properties, like a lower coefficient of thermal expansion, higher specific strength, or an increased wear resistance in comparison to non-reinforced aluminium [1-3]. The challenges of thermally joining aluminium to steel are known. A large difference between their melting points, poor solid solubility of iron in aluminium, and hence, the formation of Al-Fe intermetallic phases lower the resulting bond strengths of such joints [4-7]. Further bond strength reduction results from stress induced cracks alongside the formed brittle phases $[8,9]$. Hence, different thermal joining techniques with lowered heat input to the joining area or reduced joining times are a permanent object of research and development. Thus, friction welding, spot welding, laser-assisted welding, and brazing processes, as well as hybrid welding processes are suitable techniques to produce resilient dissimilar $\mathrm{Al} /$ steel joints [10-13]. The herein focussed arc brazing represents a cost-efficient alternative to laser-assisted welding and brazing. When AMC partners are subjected to thermal joining processes, their low thermal stability must additionally be considered. The matter becomes more pronounced, when the reinforcing particle phase comprise SiC that either thermally degrades or dissolves into the $\mathrm{Al}$ matrix, if the thermal load from the joining process is too high. Dissolving will result in brittle intermetallic $\mathrm{Al}_{3} \mathrm{C}_{4}$ precipitates and a joint strength decrease of $50 \%[14,15]$. Furthermore, the level and time of the heat input influence metallurgic 
processes at the interface between matrix and reinforcement phase and can lead to high porosity levels and chemical inhomogeneity in joining zones, if not adapted [16].

The presented work faces the above described problems. The work aim is an improved structural homogeneity of joint zones and hence higher joint strengths of dissimilar AMC/Al and AMC/steel joints in comparison to those resulting from conventional thermal joining techniques, like fusion welding, flux-aided furnace, or vacuum brazing. To achieve this aim, arc brazing is applied. Arc brazing offers the possibility to effectively minimize the heat input to joining zones. Especially, the thermal damage of AMC microstructures shall to be avoided by the combination of a focused arc with localised heat input and a low-melting braze filler. Another benefit is expected from an improved wetting of the braze filler on the substrates due to a process-inherent degradation of oxide layers at the surfaces of the metallic joining partners. The described aim could also be achieved by non-fusion welding, like friction welding, but arc brazing is chosen for its higher design flexibility regarding joint zone geometries and the non-existent wear of joining tools when processing AMC with hard-phase reinforcement.

\section{Materials and Methods}

The used AMC joining partners are from powder-metallurgically produced material EN AW-2017 + $10 \mathrm{vol} \%(\mathrm{SiC})_{\mathrm{P}}$. Stainless steel joining partners are sheets from AISI 304L, while aluminium partners are made from EN AW-6082. All surfaces to be joined are ground and polished to $R_{\mathrm{z}}<1 \mu \mathrm{m}$. Arc brazing processes are carried out using a TIG (tungsten inert gas) welding unit with alternating current (AC) of $40 \mathrm{~A}$ and Ar shielding gas (EWM, Muendersbach, Germany). Test specimens are brazed as lap joints. The braze filler is applied manually. In wetting tests, the arc is ignited next to an applied braze filler pearl of $0.1 \mathrm{~g}$ mass and subsequently moved over it. The arc is interrupted either after wetting occurred or after $4 \mathrm{~s}$ of process time to avoid melting of the base material. During joining and wetting experiments, the work distance between electrode and sample surface is approximately $10 \mathrm{~mm}$. Microstructure investigations are performed by light microscopy (LM, Olympus Europa, Hamburg, Germany), scanning electron microscopy (SEM, LEO1455VP, Carl Zeiss Microscopy, Jena, Germany), and hardness measurements according to Vickers with a force of $0.005 \mathrm{kp}$ (i.e., a load of about $5 \mathrm{~g}$ ) with an imprint duration of $15 \mathrm{~s}$ (HV0.005/15). The chemical composition of phases and larger areas like diffusion zones are examined via energy dispersive X-ray spectroscopy (EDXS, EDAX Genesis, Carl Zeiss Microscopy, Jena, Germany) and X-ray diffraction analysis (XRD, D8 "Discover", Bruker, Billerica, MA, USA) with Co-K $\alpha$ radiation (wavelength $\lambda=0.178886 \mathrm{~nm}$, phase database PDF-2014). Wetting angles are measured at cross sections images, using a digital imaging tool. Differential scanning calorimetry (DSC, Netzsch, Selb, Germany) is used to determine the melting temperature of applied braze fillers. Produced lap joints are measured regarding shear tensile strengths at test speed $v=1 \mathrm{~mm} / \mathrm{min}$ and room temperature.

The commonly used braze fillers for brazing aluminium alloys are Al-Si- or Zn-Al-based alloys [4,17-20]. Beside a better corrosion resistance of the Al-Si braze fillers, in dissimilar $\mathrm{Al} /$ steel joints Si prevents the growth of intermetallic Fe-Al phases by lowering the diffusivity of aluminium due to the formation of intermetallic Fe-Al-Si phases [21]. On the downside, the working temperature of Al-Si braze fillers is higher in comparison to $\mathrm{Zn}-\mathrm{Al}$ fillers and may exceed the solidus temperature of Al-Si-based aluminium casting alloys that are frequently used in AMC. Therefore, a recently introduced braze filler basing on a ternary Al-Ag-Cu system comprising the eutectic composition of $40 \mathrm{wt} \% \mathrm{Al}$, $40 \mathrm{wt} \% \mathrm{Ag}$ and $20 \mathrm{wt} \% \mathrm{Cu}$ is used within the presented work (B-Al40Ag40Cu20, $T_{\mathrm{m}}=506^{\circ} \mathrm{C}$ [22]). This braze filler was alloyed with $\mathrm{Si}$ to improve its wetting behaviour on stainless steel [23]. Therefore, a master alloy (B-Ag72Cu-780) is continuously casted and complemented with $\mathrm{Al}$ (purity 99.99\%) and $\mathrm{Cu}$ (purity $99.9 \%$ ) to gain the announced eutectic composition. Furthermore, $1.2-1.4 \mathrm{wt} \%$ of Si are added (purity 99.9999\%). To prevent melt pool oxidation, the braze filler production is done in inert $\mathrm{Ar}$ atmosphere. Besides positively affecting the braze filler's wetting behaviour on stainless steel, adding Si reduces its melting temperature from $506^{\circ} \mathrm{C}$ to $497^{\circ} \mathrm{C}$ in comparison to the former ternary eutectic 
composition, Table 1 . The homogeneity of alloying components within the produced braze filler rods is controlled and proven by EDXS analysis.

Table 1. Chemical compositions and melting temperatures of the eutectic and Si-alloyed braze fillers.

\begin{tabular}{ccccccc}
\hline \multirow{2}{*}{ Specification } & \multicolumn{3}{c}{ Chemical Composition (wt \%) } & \multicolumn{2}{c}{$\mathbf{T}_{\mathbf{M}}\left({ }^{\circ} \mathbf{C}\right)$} \\
\cline { 2 - 7 } & $\mathbf{A l}$ & $\mathbf{A g}$ & $\mathbf{C u}$ & $\mathbf{S i}$ & \\
\hline Eutectic Al-Ag-Cu braze filler (B-Al40Ag40Cu20) & 40 & 40 & 20 & - & 506 \\
Si-alloyed Al-Ag-Cu braze filler (B-Al39.5Ag39.5Cu20Si1) & $39.44-39.52$ & $39.44-39.52$ & $19.72-19.76$ & $1.2-1.4$ & 497 \\
\hline
\end{tabular}

\section{Results and Discussion}

\subsection{Wetting Behaviour}

The boarders between different categories of wetting behaviour are openly discussed and often related to a specific field of application. Distinctions between "good wetting" and "poor wetting", as well as "wetting" and "no wetting", however, are frequently fixed to wetting angles of either less or more than $90^{\circ}$ [24-27]. For brazing processes, an optimal wetting angle between liquid braze filler and solid joining partner is often defined as less than $30^{\circ}[24,27,28]$, but sufficient diffusion between braze filler and base material takes already place at much higher wetting angles. B-Al40Ag40Cu20 braze filler shows very good wetting when arc brazed on AMC, with wetting angles of less than $20^{\circ}$. Still satisfactory wetting is documented for it on stainless steel, with wetting angles of approximately $90^{\circ}$. As presented in a former publication, a brazing current variation between $40 \mathrm{~A}$ and $45 \mathrm{~A}$ does not visibly influence the wetting result [29]. SEM/EDXS analyses of AMC wetting samples show large diffusion zones. Qualitative XRD suggests a dominant ternary eutectic microstructure that results from the braze filler and consists of $\mathrm{CuAl}_{2}, \mathrm{Ag}_{2} \mathrm{Al}$, as well as $\mathrm{Al}$ solid solution. Close to the AMC interface, primary solidified $\mathrm{Al}$ - and $\mathrm{Al}-\mathrm{Ag}$-rich solid solutions are identified, Figures 1 and 2. XRD further reveals a content of $(\mathrm{SiC})_{\mathrm{P}}$ reinforcement that dissolved from the AMC base material as well as intermetallic $\mathrm{Al}_{7} \mathrm{Ag}_{3}$. Details are presented in and Table 2 and in [29]. Since EDXS measurements include data from a globular excitation volume of about $2 \mu \mathrm{m}$ in diameter, the presented chemical compositions of the analysed fine phases represent qualitative results, and were hence rounded to integral numbers. The results are backed up by literature data [30,31].

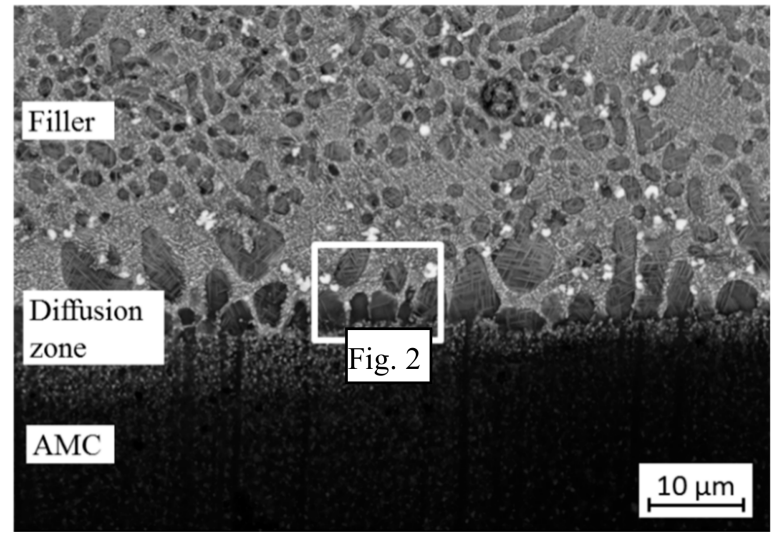

Figure 1. Microstructure (SEM) of braze filler B-Al40Ag40Cu20 wetted on AMC EN AW-2017 + 10 vol \% (SiC)P, current intensity $40 \mathrm{~A}$ [29]. 


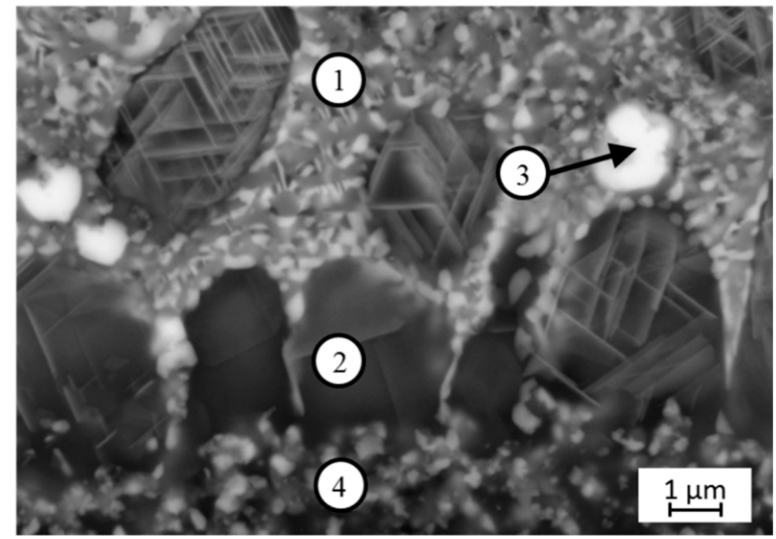

Figure 2. Braze seam of area marked in Figure 1, 1: ternary eutectic microstructure, 2: primary solidified Al-rich solid solution, 3: primary solidified Al-Ag-rich solid solution, 4: ternary eutectic microstructure [29].

Table 2. Chemical compositions (energy dispersive X-ray spectroscopy (EDXS)) of phases and detected phases (X-ray diffraction analysis (XRD)) in braze filler B-Al40Ag40Cu20 wetted on aluminium matrix composites (AMC) EN AW-2017 + $10 \mathrm{vol} \%(\mathrm{SiC})_{\mathrm{P}}$ in accordance to markings in Figure 2.

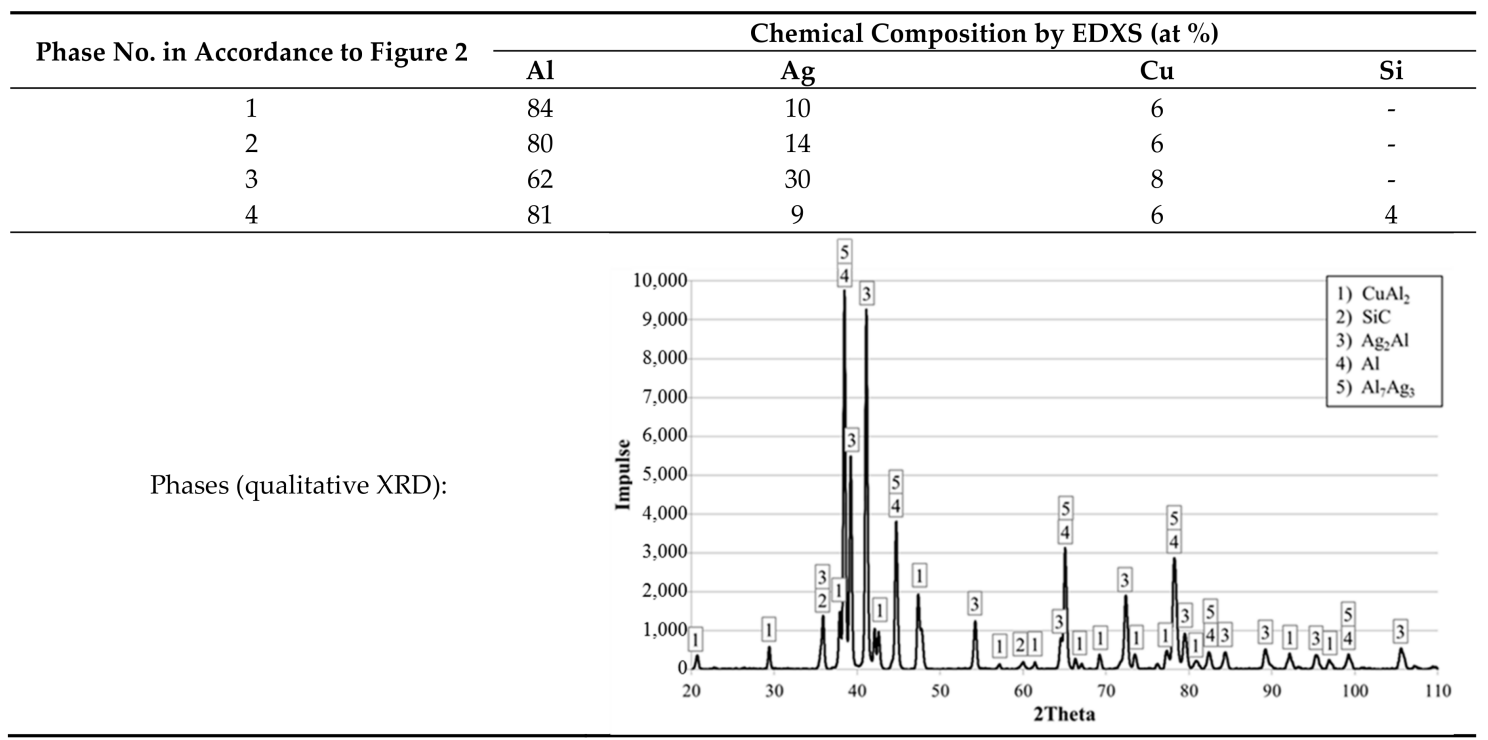

In comparison to these results, stainless steel samples wetted by B-Al40Ag40Cu20 show a compact intermetallic phase seam next to the steel interface with columnar solidified crystal structures growing in the direction of the eutectic microstructure of the braze filler, Figures 3 and 4. Compact hard phase seams can lower the resulting bond strength significantly [32]. In the case of the present material combination, thickly developed brittle seams are prone to stress cracking during joint cooling, which is induced by different coefficients of thermal expansion (CTE). 


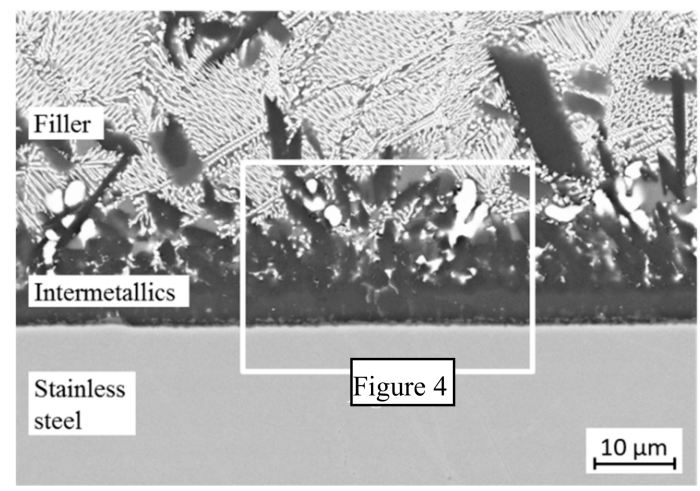

Figure 3. Microstructure (SEM) of braze filler B-Al40Ag40Cu20 wetted on stainless steel AISI 304L, braze current intensity $40 \mathrm{~A}[29]$.

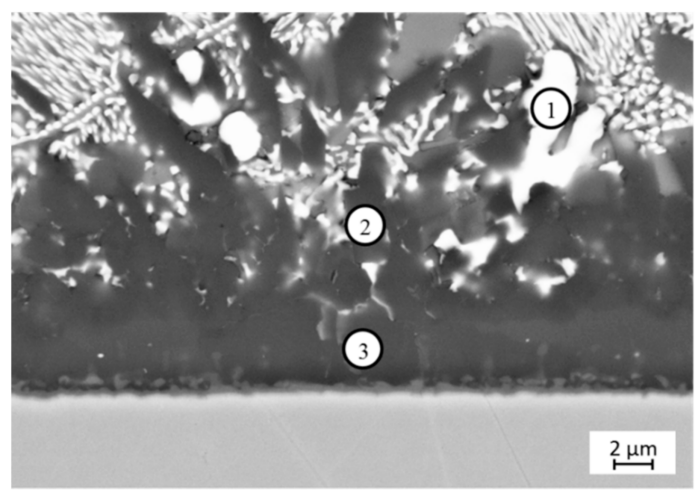

Figure 4. Braze seam of area marked in Figure 3, 1: Al-Ag-rich solid solution, 2: Fe-containing Al-rich phase (probably Al13Fe4), 3: intermetallic phase seam of Al-Fe type with contents of Cr and Ni [29].

In the present material combination, the CTE values are $23.4 \times 10^{-6} \mathrm{~K}^{-1}$ and $18 \times 10^{-6} \mathrm{~K}^{-1}$ for the braze filler and base material, respectively [33]. EDXS and XRD analyses, again being presented in detail in [29], define the columnar structures as large areas of an Al-Ag-rich phase next to a Fe-containing $\mathrm{Al}$-rich phase, whose chemical composition indicates intermetallic $\mathrm{Al}_{13} \mathrm{Fe}_{4}$. The compact phase seam probably consists of the intermetallic $\mathrm{Al}_{2} \mathrm{Fe}$ containing $\mathrm{Cr}$ and $\mathrm{Ni}$ from the base material. In addition a solid solution of $\mathrm{Fe}, \mathrm{Ni}$, and $\mathrm{Cu}$ with austenitic lattice is determined near the steel interface $[29,34]$. Details are presented in and Table 3. Again, the therein given EDXS values were rounded to integral numbers.

\subsection{Dissimilar Joints by Arc Brazing}

With regard to the Al-based joining partners, the interfaces between the processed B-Al39.5Ag39.5Cu20Si1 braze filler and the respective base material that develop during the applied arc brazing processes are similar to those that are resulting from the wetting tests. According to SEM investigations, AMC and non-reinforced aluminium EN AW-6082 both exhibit a eutectic braze seam microstructure resulting from the braze filler. Hence, the fine eutectic microstructure is interpreted as comprising the ternary eutectic phase $\mathrm{Al}_{2} \mathrm{Cu}, \mathrm{Ag}_{2} \mathrm{Al}$, as well as $\mathrm{Al}$ solid solution. At the EN AW-6082 surface an additional seam of Al solid solution is detected. This non-cohesive phase shows a higher amount of $\mathrm{Al}$ compared to the $\mathrm{Al}$ solid solution of the ternary eutectic microstructure that resulted from the wetting test, Figure $5 \mathrm{a}$. In comparison to this, the braze seam microstructure close to the AMC also shows a non-cohesive $\mathrm{Al}$ phase seam, though with lower homogeneity. In addition, due to the composition of the AMC EN AW-2017 matrix, which is closer to the composition of the braze filler in comparison to aluminium EN AW-6082, the diffusivity and formation of the ternary eutectic 
phases $\mathrm{Al}_{2} \mathrm{Cu}, \mathrm{Ag}_{2} \mathrm{Al}$, and $\mathrm{Al}$ solid solution is slightly increased. This results in a more pronounced diffusion zone of approximately twice the thickness of that on EN AW-6082, Figure 5b. The additionally observed $\mathrm{Cu}$ precipitates in the AMC base material are interpreted as a result of the heat input during brazing and a subsequent precipitation hardening effect.

Table 3. Chemical compositions (EDXS) of phases and detected phases (XRD) in braze filler B-A140Ag40Cu20 wetted on stainless steel AISI 304L in accordance to markings in Figure 4.

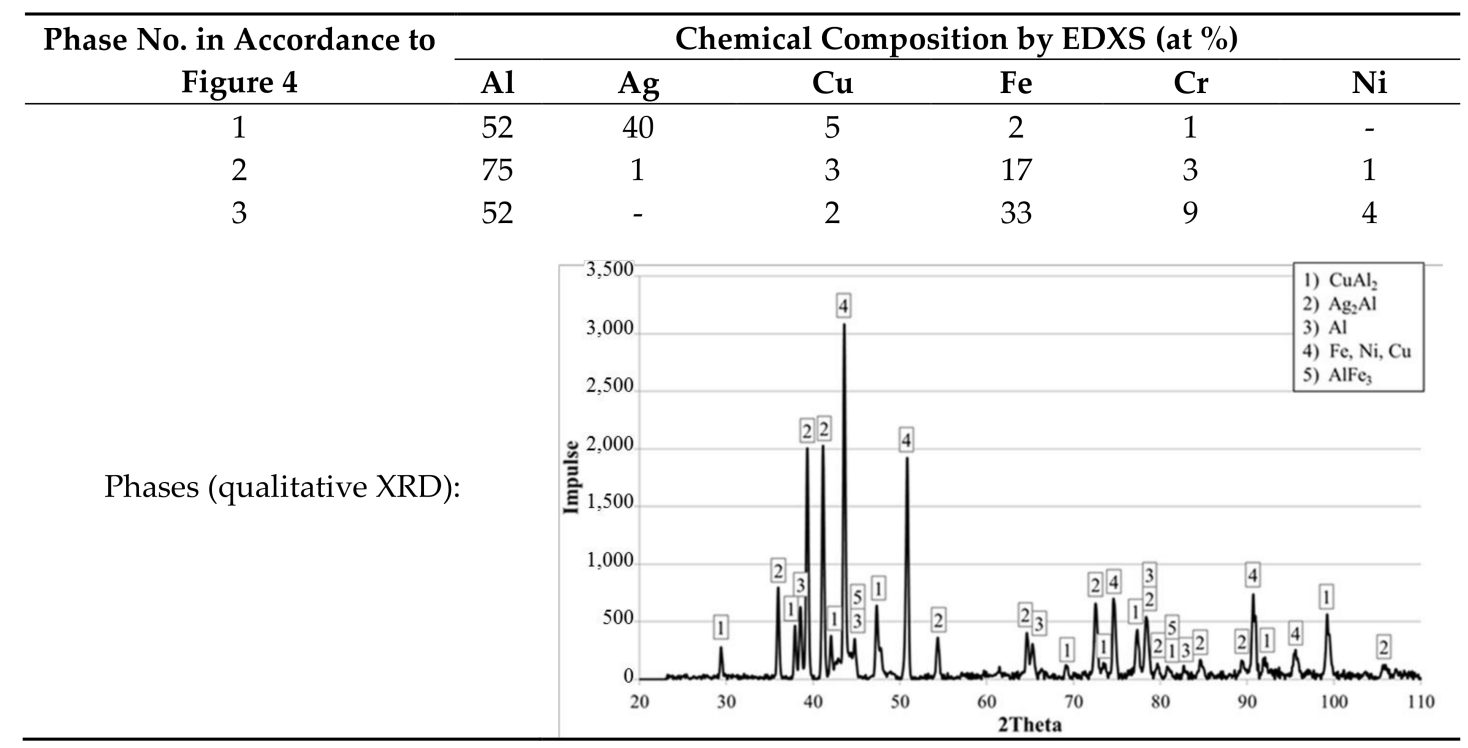

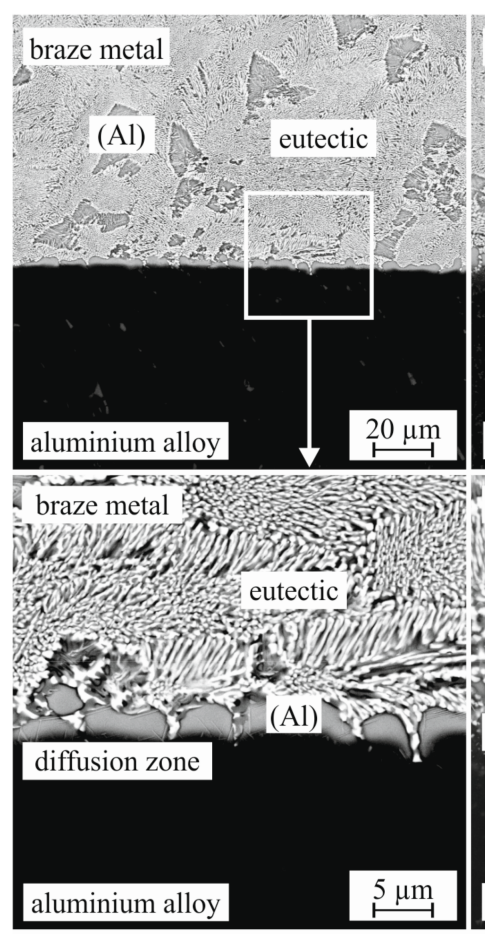

(a)
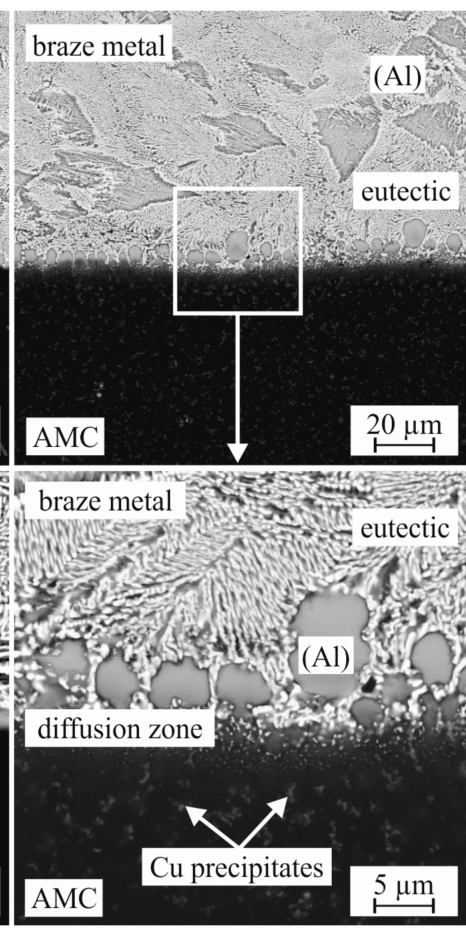

(b)

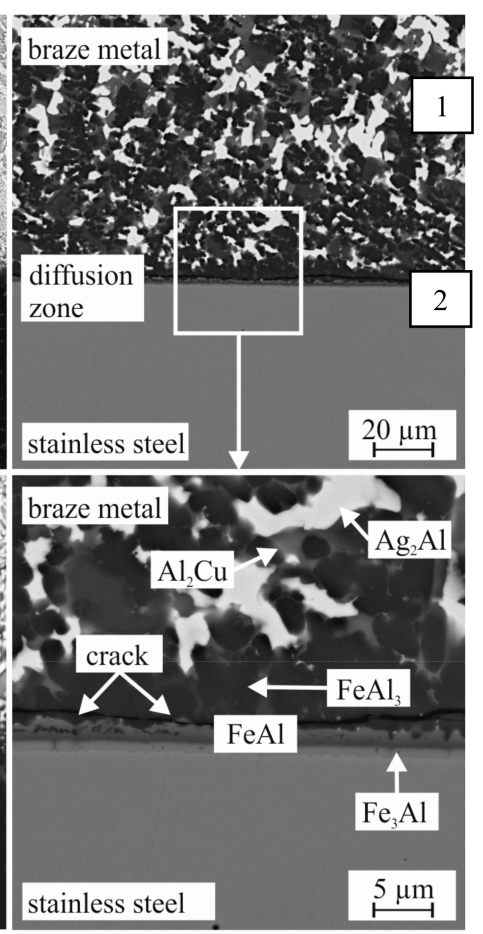

(c)

Figure 5. Microstructure (SEM) of the interfaces of braze seams between B-Al39.5Ag39.5Cu20Si1 braze filler and (a) aluminium EN AW-6082, (b) AMC EN AW-2017 + 10 vol \% (SiC) P as well as (c) stainless steel AISI 304L [35]. 
The braze seam microstructure of the interface close to stainless steel exhibits obvious differences when compared to those of Al-based joint partners as well as the results from wetting tests, Figure 5c. The respective phase detection by XRD measurements is presented in Table 4 in accordance to the marked regions in Figure $5 \mathrm{c}$ (above). The ternary eutectic microstructure of the braze filler is not existent, although $\mathrm{Al}_{2} \mathrm{Cu}$ and $\mathrm{Ag}_{2} \mathrm{Al}$ are found by qualitative XRD measurements in this region. The diffusion zone between braze seam and base material comprises at least three consistent phase layers, forming a seam of about $10 \mu \mathrm{m}$ total thickness. Qualitative XRD measurements in the interface area revealed three intermetallic phases $\mathrm{Fe}_{3} \mathrm{Al}, \mathrm{FeAl}$, and $\mathrm{Al}_{37} \mathrm{Cu}_{2} \mathrm{Fe}_{12}\left(\mathrm{Al}_{3} \mathrm{Fe}\right.$-type), which are interpreted to form this visible seam with an increasing share of $\mathrm{Al}$ in the direction of the braze seam. Detailed analysis results are presented by the authors in [35]. In SEM images, stress induced cracks are visible in the interface between the $\mathrm{FeAl}$ and $\mathrm{FeAl}_{3}$ layer, Figure $5 \mathrm{c}$ below. This failure already occurs in braze seams not subjected to mechanical load. Hence, the crack initiation can be lead back to abrupt changes in the hardness levels (FeAl: $470 \mathrm{HV} 1, \mathrm{FeAl}_{3}: 892 \mathrm{HV} 1$ ) and combined internal stresses during cooling [36]. The detection of $\mathrm{FeAl}_{3}$ in the braze seam far from the interface to the steel base material (comp. Table 4) indicates a strong alloying of the braze seam with $\mathrm{Fe}$, probably due to erosion of the steel base material.

Table 4. Detected phases (XRD) in the interface of braze seams between B-Al39.5Ag39.5Cu20Si1 braze filler and stainless steel AISI 304L in accordance to region markings in Figure 5c (above).

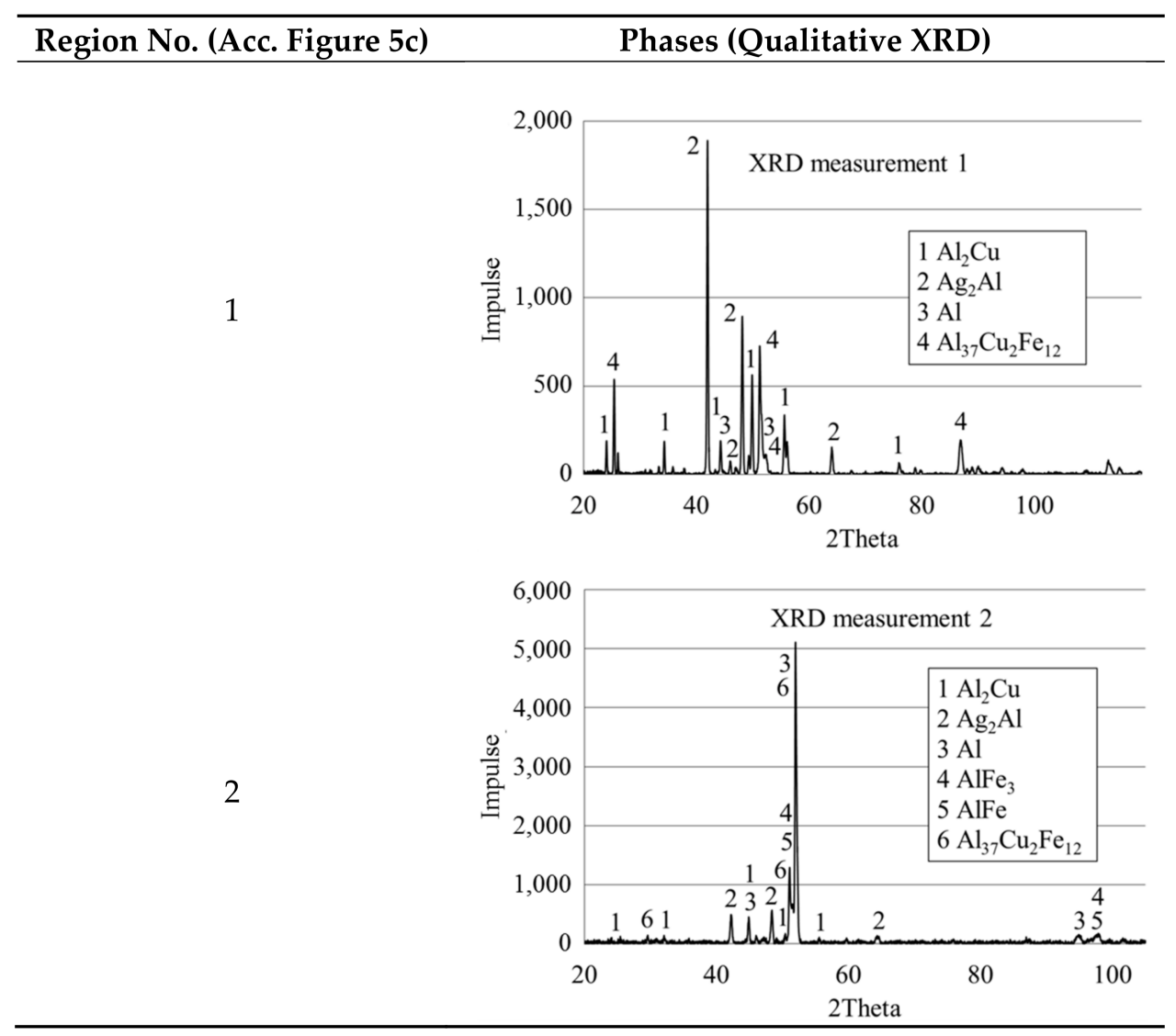

The different microstructure features of the interfaces between B-Al39.5Ag39.5Cu20Si1 braze seam and the different base materials are also visible in their respective hardness profiles, Figure 6. The displayed profiles were taken within a distance of $30 \mu \mathrm{m}$ from the braze seam/base material interface in either direction. Hardness levels are recorded in steps of $10 \mu \mathrm{m}$. To ensure the demanded distance between the measuring points according to Vickers HV0.005/15, measurements are taken 
along an offset line (cross section picture in Figure 6). A smooth hardness transition is documented between braze seam and Al-based joining partners, resulting from the Al solid solution phase that forms close to the respective interfaces. These nearly constant hardness profiles are considered to significantly lower the risk of cracks in this area, when mechanical load is applied. In contrast to this observation, the hardness increase at the interface of braze seam and stainless steel is much stronger. This results from the above documented alloying of the braze seam with $\mathrm{Fe}, \mathrm{Ni}$, and $\mathrm{Cr}$ from the steel base material and the subsequent formation of intermetallic Al-Fe phases. In the direction of the former steel surface, the content of $\mathrm{Al}$, and hence the measured hardness levels decrease from about 1000 HV0.005/15 to 500 HV0.005/15. In addition, the non-eutectic microstructure of the braze seam in this area exhibits a significantly higher hardness level than that close to the Al base materials.

The features and properties of the different microstructures in the investigated dissimilar joints become obvious in the conducted tensile shear tests. Tensile shear test samples were produced from sample sheets with height $H=1.5 \mathrm{~mm}$, width $W=10 \mathrm{~mm}$, and lengths of $L_{1} \sim 50 \mathrm{~mm}$. The joint area overlap was $L_{2}=15 \mathrm{~mm}$. Due to the arc brazing joint geometry, however, true joining areas differed from each other according to applied braze filler amount and the wettability of the base materials. The respective joining area ranges for the different dissimilar joints are given in Table 5 .

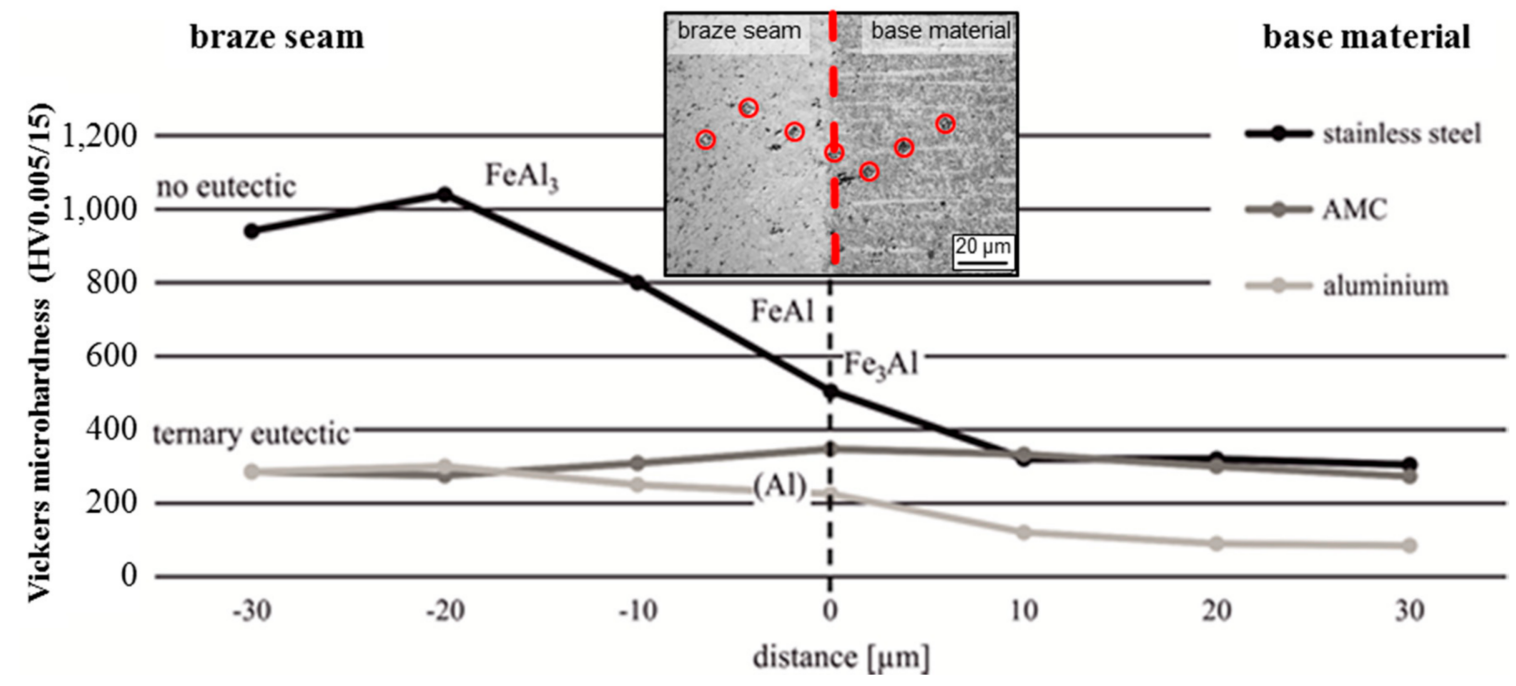

Figure 6. Hardness profiles at the investigated interfaces in dissimilar joints [35].

Figure 7 shows tensile shear strength values obtained from respective tests of braze joints of AMC EN AW-2017 + $10 \mathrm{vol} \%(\mathrm{SiC})_{\mathrm{P}}$ to itself and in dissimilar joints to EN AW-6082 and steel AISI304L. Figure 8 shows the tested specimens and areas of fracture. The developed arc brazing routine under use of the newly introduced braze filler B-A139.5Ag39.5Cu20Si1 permits AMC/AMC joints with average tensile shear strengths of about $55 \mathrm{MPa}$, showing maximum values of about $80 \mathrm{MPa}$. The resulting areas of fracture comprise partly ductile failure that mainly occur within the braze seam material close to the AMC joining partner with lower braze filler wetted area. The ductile failure is attributed to the well-developed diffusion zone between the braze seam and AMC base material in this region. In comparison to flux-aided furnace brazing processes the bond strength values are high. This is attributed to the successful oppression of $\left(\mathrm{SiC}_{\mathrm{P}}\right)$ dissolution and the related formation of aluminium carbides. Applying the same arc brazing routine and braze filler to dissimilar AMC/EN AW-6082 joints results in lower average bond strengths of about $40 \mathrm{MPa}$. Fracture occurs close to the surface of the EN AW-6082 base material. This is lead back to the underrepresented diffusion zones on the former Al alloy surfaces. The pictured fracture area in Figure 7 hence shows less ductile zones in comparison to the fracture area of AMC/AMC samples. For the applied arc brazing routine, the bond strength of dissimilarly joined AMC/AISI304L is lowest in comparison to the tensile shear strengths of 
AMC/AMC and AMC/EN AW-6082 brazing joints. The average value is about $20 \mathrm{MPa}$, which leads back to the microstructure, hardness level, and crack density that occur in the braze seam area close to the steel partner. Hence, brittle fracture occurs at the surface of the AISI304L base material. The same place of failure occurs in flux-aided brazing joints of the same type. However, in comparison to results from conventional flux-aided furnace brazing, the average bond strength value is doubled. This positive result is understood to come from a comparatively thinner seam of intermetallic phases and a finer dispersed distribution of intermetallic phases within the braze seam close to the former steel surface, when the described arc brazing routine is applied.

Table 5. True joining areas of dissimilar joints tested regarding shear tensile strength (Figures 7 and 8).

\begin{tabular}{ccccc}
\hline Braze Joint Type & AMC/AMC & AMC/EN-6082 & AMC/AISI304L (Arc Brazed) & AMC/AISI304L (Flux Brazed) \\
\hline Joining Area $\left(\mathrm{mm}^{2}\right)$ & $33-36.5$ & $26-51$ & $34-112$ & $49-85$ \\
\hline
\end{tabular}

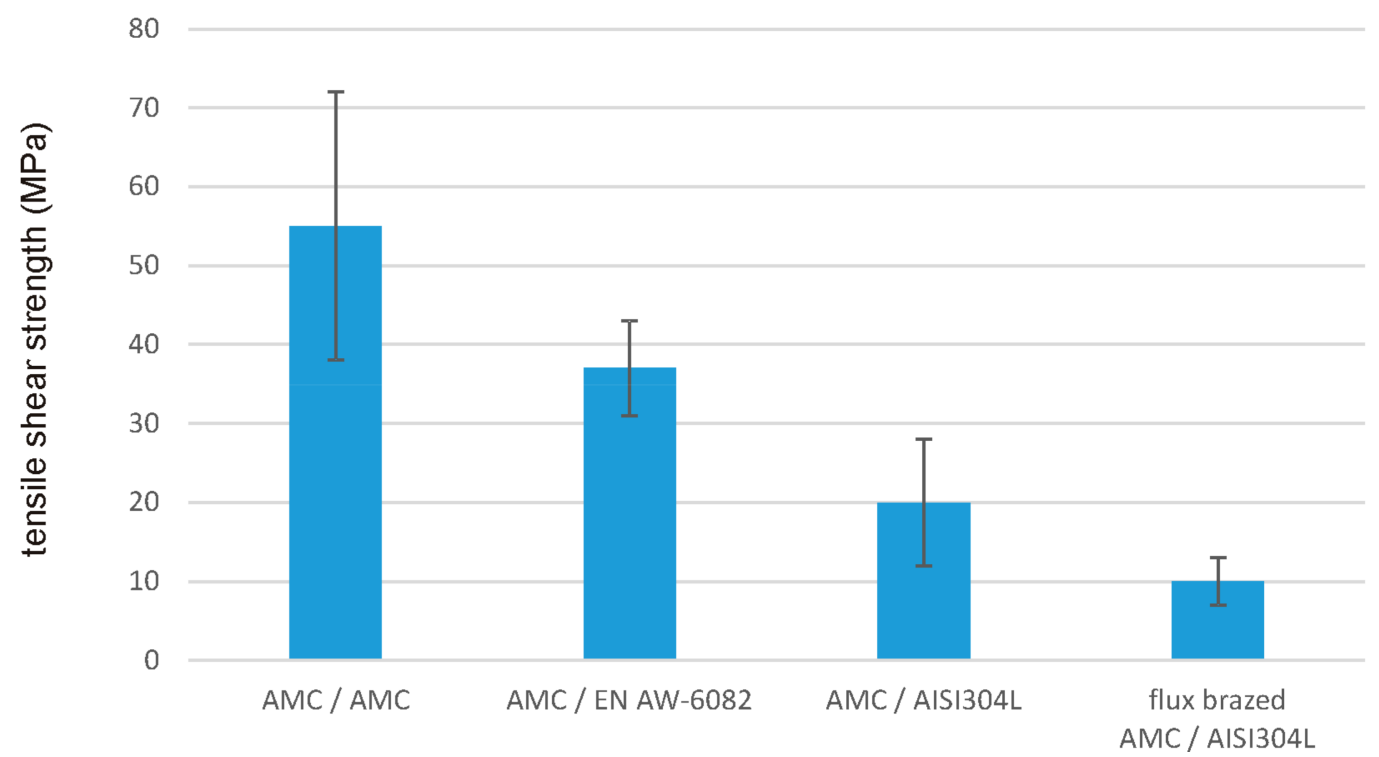

Figure 7. Bond strength values resulting from tensile shear tests for different similar and dissimilar braze joints using arc brazing routine and braze filler B-Al39.5Ag39.5Cu20Si1. 

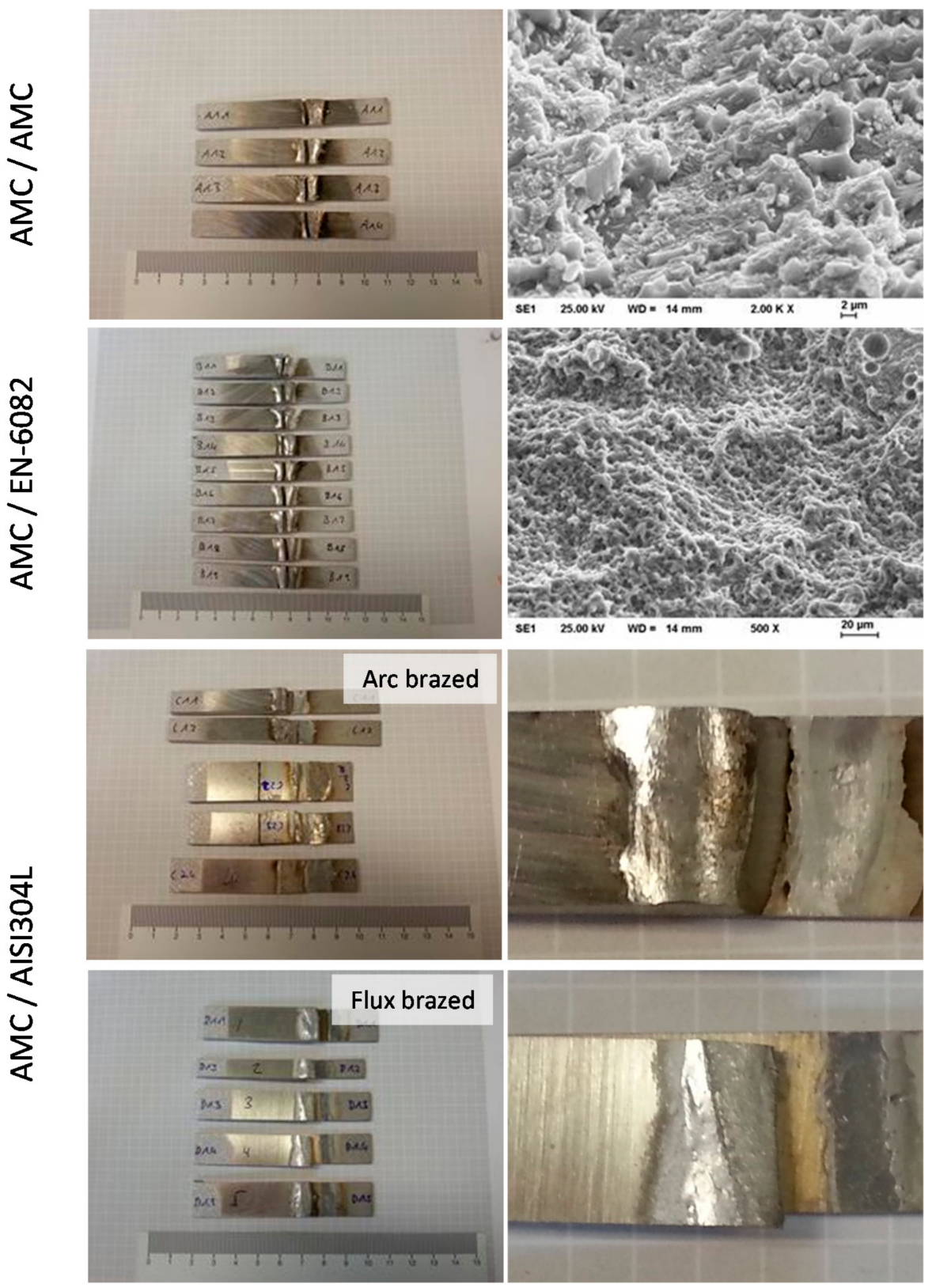

Figure 8. Tested specimens and resulting areas of fracture in accordance to the test and bond strength values presented in Figure 7.

\section{Conclusions}

Joints of particle reinforced aluminium matrix composites to itself, stainless steel, and aluminium alloy were successfully produced by arc brazing. The investigation of the microstructures of the developed braze filler and the produced joints proved that the resulting thermal influence on the processed aluminium materials is low, which results in thin diffusion zones. Additionally, it is noticeable that the ternary eutectic microstructure of the braze filler still exists within the braze seam close to the aluminium-based joining partners. The hardness profile at the interfaces between braze seam and aluminium alloy as well as AMC is accordingly flat, showing nearly constant hardness levels of approximately $300 \mathrm{HV} 0.005 / 15$. The nearly constant hardness levels lead to high average bond strengths of these brazing joints of about $40 \mathrm{MPa}$ and $55 \mathrm{MPa}$, respectively. In contrast to this, the interfaces of the braze seam to stainless steel showed detrimental microstructures and hardness 
profiles, due to severe alloying of the braze filler during arc brazing. As a result, various intermetallic phases and phase seams formed instead of the announced ternary eutectic microstructure that was documented for braze seam areas that are close to the Al-based joining partners. However, the resulting average bond strength of $20 \mathrm{MPa}$ was twice as high as that gained for comparatively produced conventionally furnace-brazed AMC/steel joints.

In summary, arc brazing is a suitable technique to join $\mathrm{AMC}$ to $\mathrm{Al}$ alloys with high bond strengths. Permanent arc brazed joints of AMC to steel could be produced, however, shear tensile tests revealed significantly lower bond strengths due to a persistent brittle phase seam at the surface of the steel partner. Hence, further adapted brazing processes are necessary to reduce heat input and to prevent the formation of brittle intermetallic phases, especially seams of intermetallic Fe-Al phases.

Acknowledgments: The authors gratefully acknowledge the funding by the German Research Foundation (Deutsche Forschungsgemeinschaft, DFG) within the framework of the Collaborative Research Centre 692 (SFB HALS 692).

Author Contributions: Thomas Grund and Andreas Gester finished the joining experiments and the investigations and characterization of the joint properties. Thomas Grund is also the main author of this manuscript. Thomas Grund and Peter Mayr are senior scientists, who developed and supervised the project "Joining concepts for bulk and sheet metal structures of high-strength light-weight materials" within SFB HALS 692. Guntram Wagner is a senior scientist who holds the chair of the Composite Materials and Material Compounds group and advised and supervised the brazing experiments.

Conflicts of Interest: The authors declare no conflicts of interest.

\section{References}

1. Xiu, Z.; Yang, W.; Chen, G.; Jiang, L.; Mac, K.; Wu, G. Microstructure and tensile properties of $\mathrm{Si}_{3} \mathrm{~N}_{4 \mathrm{p}} / 2024 \mathrm{Al}$ composite fabricated by pressure infiltration method. Mater. Des. 2012, 33, 350-358. [CrossRef]

2. Sajjadi, S.A.; Ezatpour, H.R.; Parizi, M.T. Comparison of microstructure and mechanical properties of A356 aluminium alloy $/ \mathrm{Al}_{2} \mathrm{O}_{3}$ composites fabricated by stir and compo-casting processes. Mater. Des. 2012, 34, 106-111. [CrossRef]

3. Qu, X-h; Zhang, L.; Wu, M.; Ren, S.-b. Review of metal matrix composites with high thermal conductivity for thermal management applications. Prog. Nat. Sci. Mater. Int. 2011, 21, 189-197.

4. Song, J.L.; Lin, S.B.; Yang, C.L.; Ma, G.C.; Liu, H. Spreading behavior and microstructure characteristics of dissimilar metals TIG welding-brazing of aluminum alloy to stainless steel. Mater. Sci. Eng. A 2009, 509, 31-40. [CrossRef]

5. Uzun, H.; Dalle Donne, C.; Argagnotto, A.; Ghidini, T.; Gambaro, C. Friction stir welding of dissimilar Al 6013-T4 to X5CrNi18-10 stainless steel. Mater. Des. 2005, 26, 41-46. [CrossRef]

6. Liu, H.W.; Guo, C.; Cheng, Y.; Liu, X.F.; Shao, G.J. Interfacial strength and structure of stainless steel-semi-solid aluminum alloy clad metal. Mater. Lett. 2006, 60, 180-184. [CrossRef]

7. Steiners, M.; Höcker, F. Einfluss der Beschichtungen beim stoffschlüssigen Lichtbogen-fügen von Stahl mit Aluminium. Mater. Werkst. 2007, 38, 559-564. [CrossRef]

8. Dong, H.; Yang, L.; Dong, C.; Kou, S. Arc joining of aluminum alloy to stainless steel with flux-cored Zn-based filler metal. Mater. Sci. Eng. A 2010, 527, 7151-7154. [CrossRef]

9. Lin, S.B.; Song, J.L.; Yang, C.L.; Fan, C.L.; Zhang, D.W. Brazability of dissimilar metals tungsten inert gas butt welding-brazing between aluminum alloy and stainless steel with Al-Cu filler metal. Mater. Des. 2010, 31, 2637-2642. [CrossRef]

10. Ding, Y.; Shen, Z.; Gerlich, A.P. Refill friction stir spot welding of dissimilar aluminum alloy and AlSi coated steel. J. Manuf. Proc. 2017, 30, 353-360. [CrossRef]

11. Sakiyama, T.; Murayama, G.; Naito, Y.; Saita, K.; Miyazaki, Y.; Oikawa, H.; Nose, T. Dissimilar Metal Joining Technologies for Steel Sheet and Aluminum Alloy Sheet in Auto Body. Nippon Steel Technol. Rep. 2013, 103, 91-98.

12. Casalino, G.; Leo, P.; Mortello, M.; Perulli, P.; Varone, A. Effects of Laser Offset and Hybrid Welding on Microstructure and IMC in Fe-Al Dissimilar Welding. Metals 2017, 7, 282. [CrossRef]

13. Kimura, M.; Ishii, H.; Kusaka, M.; Kaizu, K.; Fuji, A. Joining phenomena and fracture load of friction welded joint between pure aluminium and low carbon steel. Sci. Technol. Weld. Join. 2009, 14, 388-395. [CrossRef] 
14. Prater, T. Solid-state joining of metal matrix composites: A survey of challenges and potential solutions. Mater. Manuf. Proc. 2011, 26, 636-648. [CrossRef]

15. Lean, P.P.; Gil, L.; Ureña, A. Dissimilar welds between unreinforced AA6082 and AA6092/SiC/25p composite by pulsed-MIG arc welding using reinforced filler alloys (Al-5Mg and Al-Si). J. Mater. Proc. Technol. 2003, 143, 846-850. [CrossRef]

16. Ureña, A.; Escalera, M.D.; Gil, L. Influence of interface reactions on fracture mechanisms in TIG arc-welded aluminium matrix composites. Compos. Sci. Technol. 2000, 60, 613-622. [CrossRef]

17. Qin, G.; Lei, Z.; Su, Y.; Fu, B.; Meng, X.; Lin, S. Large spot laser assisted GMA brazing-fusion welding of aluminium alloy to galvanized steel. J. Mater. Proc. Technol. 2014, 214, 2684-2692. [CrossRef]

18. Wielage, B.; Klose, H. Das Aluminiumlöten von Wärmetauschern. DVS-Rep. 1995, 166, 88-90.

19. Wielage, B.; Martinez, L. Aluminiumlöten bei $550{ }^{\circ} \mathrm{C}$-Eigenschaften von ZnAl-Verbindungen. DVS-Rep. 2001, 212, 214-217.

20. Wielage, B.; Trommer, F. Löten von Aluminium mit Zinkbasisloten. Schweiß. Schneid. 2003, 5, $273-275$.

21. Song, J.L.; Lin, S.B. Effects of Si additions on intermetallic compound layer of aluminum-steel TIG welding-brazing joint. J. Alloys Comp. 2009, 488, 217-222. [CrossRef]

22. Elßner, M.; Weis, S.; Grund, T.; Hausner, S.; Wielage, B.; Wagner, G. Lichtbogenlöten von Aluminiummatrix-Verbundwerkstoffen mit AlAgCu-Loten. Werkstoffe und werkstofftechnische Anwendungen 2014, 52, 181-186.

23. Elßner, M.; Weis, S.; Wagner, G. Joining of Aluminum Matrix Composites and Stainless Steel by Arc Brazing. Mater. Sci. Forum 2015, 825, 393-400. [CrossRef]

24. Dorn, L. Hartlöten und Hochtemperaturlöten; Expert Verlag: Renningen, Germany, 2007.

25. Yuan, Y.; Lee, T.R. Contact Angle and Wetting Properties; Springer: Heidelberg/Berlin, Germany, 2013.

26. Zaremba, P. Hart- und Hochtemperaturlöten; Verlag fuer Schweisstechnik DVS-Verlag: Duesseldorf, Germany, 1988.

27. N.N. Brazing Handbook; American Welding Society: Miami, FL, USA, 1991.

28. Müller, W.; Müller, J.-U. Löttechnik—Leitfaden für die Praxis; Verlag fuer Schweisstechnik DVS-Verlag: Duesseldorf, Germany, 1995.

29. Weis, S.; Elßner, M.; Wielage, B.; Wagner, G. Wetting behavior of AlAgCu brazing filler on aluminum matrix composites and stainless steel. Weld. World 2017, 61, 383-389. [CrossRef]

30. Liu, S.; Zhao, S.; Zhang, Q. Phase Diagram of the Aluminium-Copper-SilverAlloy System. Acta Metall. Sin. 1983, 19, 70-73.

31. Witusiewicz, V.T.; Hecht, U.; Fries, S.G.; Rex, S. The Ag-Al-Cu system: II. A thermodynamic evaluation of the ternary system. J. Alloys Comp. 2005, 387, 217-227. [CrossRef]

32. Schmid, G.; Wetter, H. Stanzniet- und Hybridfügeverfahren im Karosseriebau; Konferenzband Join-Tec: Halle, Germany, 2005; pp. 42-57.

33. Data Sheet 1.4301. Available online: http://www.ll-adelsdorf.com/pdfdoku/Edelstahl/1.4301.pdf (accessed on 13 June 2014).

34. Springer, H.; Kostka, A.; Dos Santos, J.F.; Raabe, D. Influence of intermetallic phases and Kirkendall-porosity on the mechanical properties of joints between steel and aluminium alloys. Mater. Sci. Eng. A 2011, 528, 4630-4642. [CrossRef]

35. Elßner, M.; Weis, S.; Wagner, G.; Grund, T. Joining of material compounds of aluminium matrix composites (AMC) by arc brazing using Al-Ag-Cu system filler alloy. Weld. World 2017, 61, 405-411. [CrossRef]

36. Potesser, M.; Schoeberl, T.; Antrekowitsch, H.; Bruckner, J. The Characterization of the Intermetallic Fe-Al Layer of Steel-Aluminum Weldings. EPD Congr. 2006, 1, 167.

(C) 2018 by the authors. Licensee MDPI, Basel, Switzerland. This article is an open access article distributed under the terms and conditions of the Creative Commons Attribution (CC BY) license (http:/ / creativecommons.org/licenses/by/4.0/). 